\title{
SERUM LIPIDS AND LIPOPROTEIN IN HYPERTENSION AND ISCHEMIC HEART DISEASE
}

\author{
Shigeo Koike, Michiko Komaya, Kenji Ikoma, Eiko Horiuchi \\ Department of Hygiene, School of Medicine, Showa University, Tokyo \\ Tadataka Nagami \\ Toshiba Rinkan Hospital, Tokyo
}

Numerous reports have demonstrated that various serum lipids, especially cholesterol and triglyceride, relate to atherosclerosis. It has been accepted that atherosclerosis is one of the most frequent causes of ischemic heart disease, and many investigators have reported that the average values for the serum concentration of cholesterol and several other lipids are higher in groups of patients, who have ischemic heart disease compared with those in a group of normal persons. In this country cerebrovascular accidents following hypertension have been a leading cause of death as opposed to Western Society where deaths are largely due to cardiac complications. In western countries hypertension was regarded as accelerating the progress of established atherosclerosis, but among the Japanese, in whom atherosclerosis of the coronary stem is not frequently seen ${ }^{1)}$, the relationship between hypertension and the atherosclerosis of coronary arteries may be not so simple or clear. The low incidence of coronary heart diseases in this country in spite of hypertension common among the Japanese may be explained from the fact that severe attack of atherosclerosis is uncommon related to the low intake of dietary fat. Since World War II, however, a change in diet has been observed among the large city population and the prevalence of coronary heart disease is reported increasing in this country. ${ }^{2)}$

The aim of the investigation was to make clear the following points:

1) Are the average serum lipid and lipoprotein levels in hypertensives or subjects with ischemic heart disease higher than those of healthy controls of the comparable age?

2) Are there any differences in the lipid and lipoprotein levels among the stages of hypertension?

\section{MATERIALS AND METHODS}

The subjects were selected at random from the population of Tokyo and its suburbs, viz. students of Showa Medical School, Health Examinees the human dock of Japan Red Cross Central Hospital, in- and out-patients of Toshiba Rinkan Hospital and Yokohama MinamiKyosai Hospital, and members of clubs for the aged. 215 men and women over 20 years were examined from October 1964 to August 1966. The examination consisted of a case history and family history, physical examination, urinary examination for protein and glucose, blood pressure, reading a 12-lead electrocardiographic tracing and digital plethysmographs taken at rest. Criteria employed for the diagnosis of ischemic heart disease and stage of hypertension were according to Komachi's classification, ${ }^{3)}$ which is a slight modification of the one recommended by the W. H. O. Comittee on Hypertension and Ischemic Heart Disease ${ }^{4}$.

Blood samples were obtained by veinpuncture from fasting persons. Serum total cholesterol was determined by the method described by Abell et al.,5) triglyceride by the Kawade modification $^{6)}$ of the procedure of Van Handel and Zilversmit, and serum $\beta$-lipoprotein lipids as well as $\beta$-lipoprotein cholesterol by Dangerfield and Faulkerer, ${ }^{7)}$ which is a modification method of Burstein et al. Dextran sulphate of molecular weight approximately 16,000 (Sigma comp. 
Ltd.) was used for the precipitation of $\beta$-lipoprotein in turbidity test.

\section{RESULTS}

\section{Serum Lipid and Lipoprotein in different Age Group of Normal Subjects.}

1) Triglyceride: in order to reduce the skewness in the distribution of triglyceride, each value was converted into the corresponding logarithmic one. In men, no significant difference could be observed among the age group and the average of $81.2 \mathrm{mg} / \mathrm{dl}$ was obtained in this group. There was no significant difference between the age group of $40-59$ and over 60 in women, and between the men and women over 40 years (Fig. 1), (Table 1). Average of 87.1 $\mathrm{mg} / \mathrm{dl}$ was obtained in women over 40 years.

2) $\beta$-lipoprotein lipid: In men, $\beta$-lipoprotein lipid showed no significant age differences and average value of $672.2 \mathrm{mg} / \mathrm{dl}$ was observed in this group. In women, however, there was a significant difference between the age groups of 40-59 and over 60 years and corresponding figures were 731.2 and $837.9 \mathrm{mg} / \mathrm{dl}$. Though higher values were observed in female groups than those of men, no significant difference could be noted despite the differcnt sexes.

3) Total cholesterol: total cholesterol in men increased with age but in women over 40 years no significant increase with age was observed.

4) $\beta$-lipoprotein cholesterol: as shown in Fig. $1, \beta$-cholesterol in men tends to increase from 50 years but no significant difference was observed among age groups.

2. Serum Lipid and Lipoprotein Levels in Hypertensives and Ischemic Heart Disease.

1) Triglyceride: as shown in Fig. 1, and Table 2-3, hypertensive subjects and patients for ischemic heart disease exhibit an increased concentration of triglyceride compared with normal persons of comparable age. Statistically significant increase in triglyceride level, however, was observed only in the stage 1 and 2 of male hypertensives aged 40-59 and in the stage 2 and 3 of female hypertensives over 40 years in comparison with healthy controls of comparable age.

2) $\beta$-lipoprotein lipid: hypertensives and ischemic heart disease patients show the increased levels of $\beta$-lipoprotein lipid in both sexes, compared with normal groups of comparable ages. Statistically significant higher values are observed in men aged 40-59, in male coronary patients group over 60 years and stage 2 and 3 groups of female hypertensives.

3) Total cholesterol: In men 40-59 years and women over 40 years, each coronary heart disease and hypertensive group show an increase in concentrations of total cholesterol in comparison with those of control healthy ones. However, statistically significant higher values were noted only in the hypertensives of stage 1 and 2 , and male coronary patients aged 40 59.

4) $\beta$-lipoprotein cholesterol: In $\beta$-lipoprotein cholesterol concentration of men aged 40 59 and women over 40 years, results similar to the total cholesterol were obtained. Statistically significant differences were observed, however, only in men aged 40-59 among coronary patients, all stages of hypertensives and normal subjects.

5) No significant difference was observed during each developing stage of hypertension as far as the serum lipids and lipoproteins were concerned.

\section{DISCUSSION}

In spite of remarkable westernization in the mode of living in urban areas of this country, the great majority of Japanese still consume low fat and low animal protein diet. The daily fat intake of about $30 \mathrm{gm}$ is derived from vegetables and fish, and accounts for about 15 per 
Fig. 1. Serum lipids and lipoproteins in healthy control, subjects with ischemic heart disease and hypertensives.

$\mathrm{C}=$ Control

$\mathrm{IHD}=$ Ischemic Heart Disease
$1 \mathrm{H}=$ Stage 1 Hypertension

$2 \mathrm{H}=$ Stage 2 Hypertension $3 \mathrm{H}=$ Stage 3 Hypertension

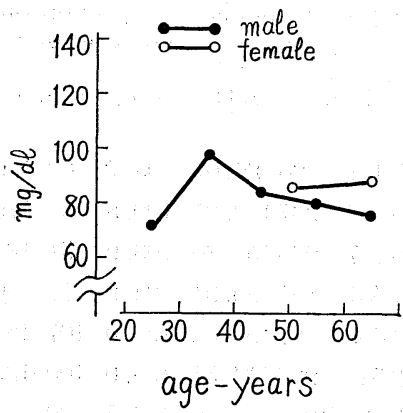

Triglyceride
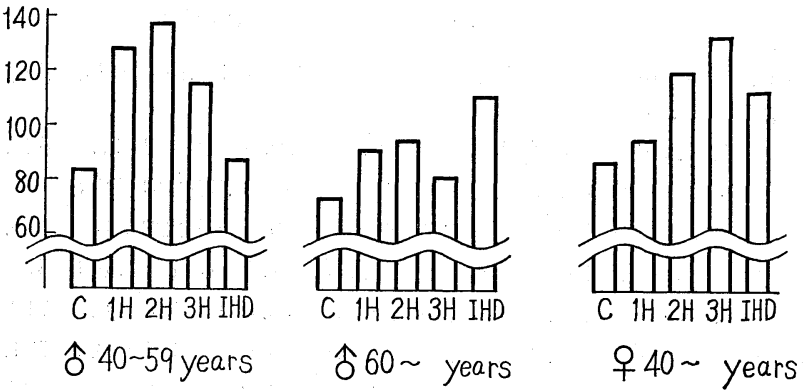

Total Cholesterol \& $\beta$-Lipoprotein Cholesterol
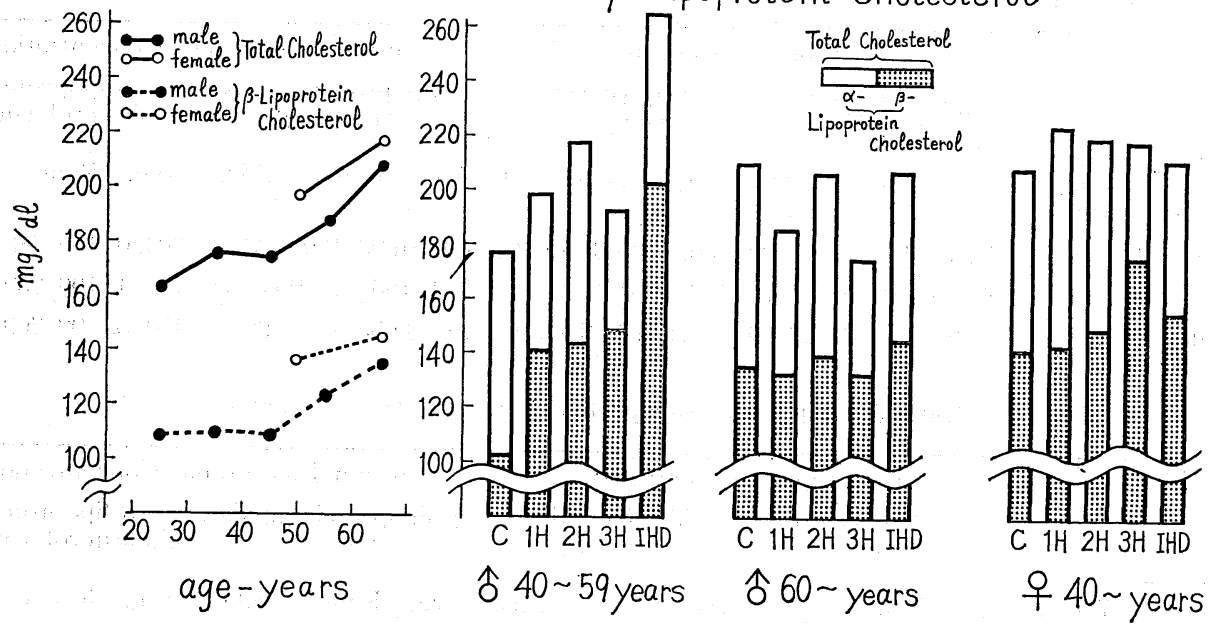

$\beta$-Lipoprotein Lipid
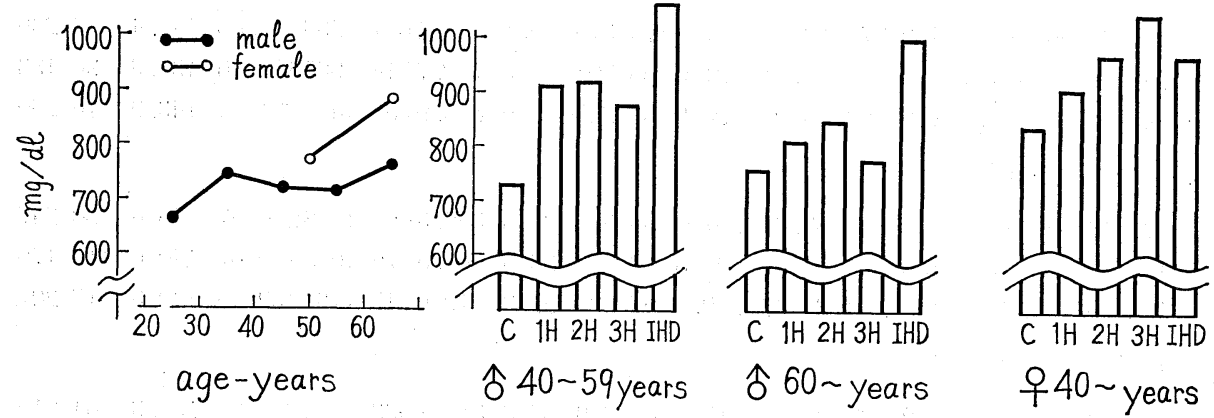

cent of the caloric intake. In the Japanese, the normal values of cholesterol, which was determined by the Zak-Henry method, is reported to be $108-239 \mathrm{mg} / \mathrm{dl}$, average $161 \mathrm{mg} / \mathrm{dl} .^{9}$ ) 
The cholesterol levels determined by the method of Abell et al, which was adopted by us in the investigation, were said to be slightly lower than those by the Zak-Henry's. We selected the subjects from the urban inhabitants, who probably consume more fat compared with general

Table 1. Lipid and Lipoprotein Levels is Control Group Individuals

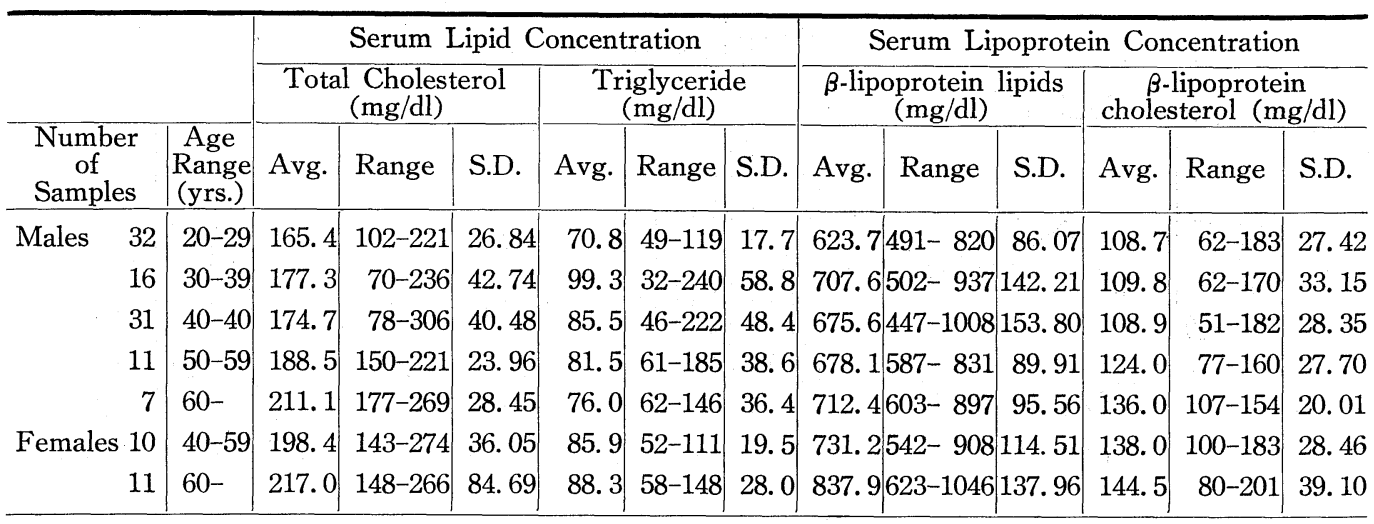

Table 2. Lipid and Lipoprotein Levels in Individuals with Ischemic Heart Disease

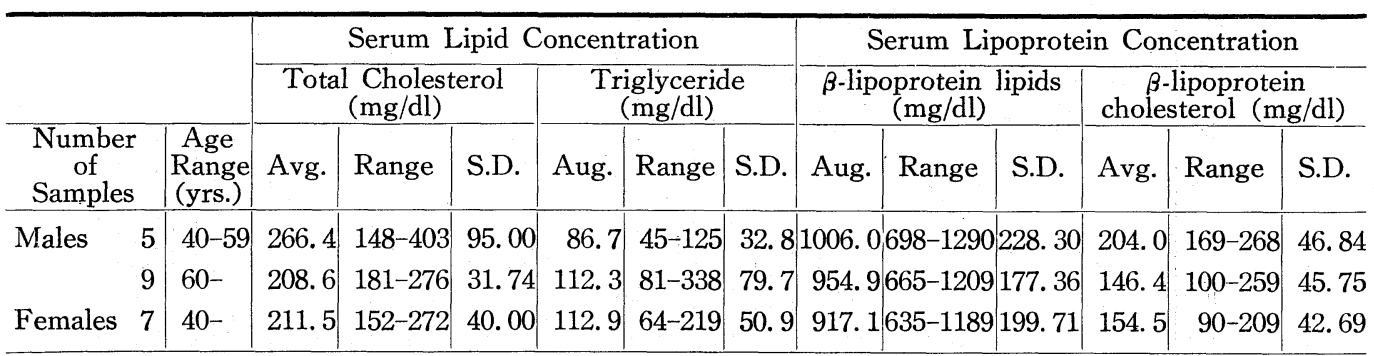

Table 3. Lipid and Lipoprotein Levels in Hypertensives

\begin{tabular}{|c|c|c|c|c|c|c|c|c|c|c|c|c|c|}
\hline \multirow[b]{3}{*}{$\begin{array}{l}\text { Number } \\
\text { of } \\
\text { Samples }\end{array}$} & \multirow[b]{3}{*}{\begin{tabular}{|l|} 
Age \\
Range \\
(yrs.)
\end{tabular}} & \multicolumn{6}{|c|}{ Serum Lipid Concentration } & \multicolumn{6}{|c|}{ Serum Lipoprotein Concentration } \\
\hline & & \multicolumn{3}{|c|}{$\begin{array}{c}\text { Total Cholesterol } \\
(\mathrm{mg} / \mathrm{dl})\end{array}$} & \multicolumn{3}{|c|}{$\begin{array}{c}\text { Triglyceride } \\
(\mathrm{mg} / \mathrm{dl})\end{array}$} & \multicolumn{3}{|c|}{$\begin{array}{c}\beta \text {-lipoprotein lipids } \\
(\mathrm{mg} / \mathrm{dl})\end{array}$} & \multicolumn{3}{|c|}{$\begin{array}{c}\beta \text {-lipoprotein } \\
\text { cholesterol (mg/dl) }\end{array}$} \\
\hline & & Avg. & Range & S.D. & Avg. & Range & S.D. & Avg. & Range & S.D. & Avg. & Range & S.D. \\
\hline
\end{tabular}

Stage 1 of Hypertension

\begin{tabular}{lr|r|r|r|r|r|r|r|r|r|r|r|r|} 
Males & 13 & $40-59$ & 205.6 & $150-276$ & 33.97 & 127.9 & $70-376$ & 95.1 & $863.4611-1238$ & 172.85 & 142.4 & $79-230$ & 44.90
\end{tabular}

\begin{tabular}{l|l|l|l|l|l|l|l|l|l|l|l|l|l}
14 & $60-$ & 187.1 & $118-231$ & 27.51 & 91.6 & $58-205$ & 52.3 & 761.7 & $518-987$ & 156.66 & 134.3 & $90-183$ & 27.73
\end{tabular}

\begin{tabular}{l|l|l|l|l|l|l|l|l|l|l|l|l|} 
Females 14 & $40-$ & 224.5 & $176-363$ & 44.91 & 95.9 & $53-225$ & 49.6 & $863.9583-1463$ & 221.84 & 143.9 & $76-260$ & 44.30
\end{tabular}

Stage 2 of Hypertension

\begin{tabular}{lr|r|r|r|r|r|r|r|r|r|r|r|} 
Males $\quad 7$ & $40-59$ & 219.3 & $156-353$ & 69.24 & 137.8 & $83-372$ & 97.8 & $869.3663-1368$ & 236.57 & 145.6 & $90-247$ & 57.37
\end{tabular}

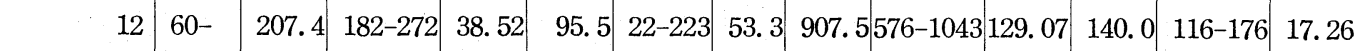

\begin{tabular}{l|l|l|l|l|l|l|l|l|l|l|l|l|l|} 
Females 14 & $40-$ & 220.2 & $162-280$ & 34.48 & 120.6 & $67-226$ & 51.8 & $919.6715-1135$ & 139.05 & 149.8 & $117-207$ & 30.80
\end{tabular}

Stage 3 of Hypertension

\begin{tabular}{lr|r|r|r|r|r|r|r|r|r|r|r|r|} 
Males & 8 & $40-59$ & 193.8 & $140-232$ & 27.57 & 115.7 & $45-219$ & 57.3 & 821.1 & $533-973225.02$ & 151.3 & $64-210$ & 43.17
\end{tabular} \begin{tabular}{l|l|l|l|l|l|l|l|l|l|l|l|l|l}
16 & $60-$ & 176.2 & $105-257$ & 49.55 & 83.2 & $35-229$ & 57.7 & $735.0520-990$ & 144.42 & 134.4 & $83-190$ & 32.11
\end{tabular}

\begin{tabular}{ll|l|l|l|l|l|l|l|l|l|l|l|l|l|} 
Females 8 & $40-$ & 219.3 & $148-279$ & 42.24 & 133.8 & $70-208$ & 70.6 & 991.7 & $818-1159$ & 149.94 & 176.0 & $104-231$ & 45.97 \\
\hline
\end{tabular} 
Japanese. Our data correspond to the serum total cholesterol level of healthy dwellers in Tokyo and its suburbs determined by Hayashi et al. ${ }^{10)}$ using a modified method of Zak-Henry. It has been a frequent finding that the concentration of cholesterol increases with advancement of age and our data also showed this same tendency. The normal serum cholesterol levels of each decade are lower than those of comparable age in the population of Norway, ${ }^{11}$ the citizens of Stockholm Sweden, ${ }^{12)}$ and a multiracial group of office personnel of various nationalities employed in an insurance group located in Metropolitan New York City. ${ }^{13)}$

It is accepted that the content of animal fats in the diet is a major factor determining the level of plasma cholesterol and the incidence of artery disease in the general population. The average high concentration of the serum cholesterol in male patients suffering from ischemic heart disease of the age from 40 to 59 is consistent with above hypothesis, but a rather low level of serum cholesterol in female coronary patients of age over 40 as well as male over 60 years are incompatible above hypothesis. The rather low values for serum cholesterol in male patients with coronary disease over 60 years in this study is in agreement with results obtained by Albrink, ${ }^{4)}$ Kroman et al. ${ }^{15)}$ and Scarborough et al.. ${ }^{16)}$

In the age group of females over 40 years, no significant difference was found between cholesterol level of patients with coronary artery disease and normal women which agrees with the result obtained by Kroman et al.. ${ }^{15)}$

Obeyesekere $^{17)}$ estimated the fat consumption of 200 patients suffering from ischemic heart disease in Ceylon and found to be low compared with Western standards. He thought that dietaly fat did not play an important role in the etiology of ischemic heart disease which is common in Ceylon. Gore et al. ${ }^{18)}$ made a comparative study of aortic atherosclerosis in the United States and Japan from the pathological standpoint and concluded that atherosclerosis of the coronary arteries seems to have no marked difference between U.S.A. and Japan, but there is a prominent difference in its severity. Donomae et al. ${ }^{1}{ }^{1}$ ascribed the difference in severity to the intramuscular sclerosis of the small coronary arteries, which is an important cause of heart disease in people with a low grade of atherosclerosis such as the Japanese. .

The mean values for serum triglyceride in normal men 40,50 and 60 age groups were $85,81,76 \mathrm{mg} / \mathrm{dl}$ respectively. Each of these values is lower than that in comparable age group in western countries, ${ }^{19)}$ and slightly lower than the data reported by Kunito, ${ }^{20)}$ who measured serum triglyceride in normal male Japanese of age ranging from 20 to 79 years, living in urban areas. The difference between our data and Kunito's may be due to the adopted method of determination. He reported that the serum triglyceride values in 20-29 and 60-70 years groups were significantly lower than those of the other age groups. Age trend of our data confirms this finding. The distribution of serum triglyceride in each healthy male age group showed a normal curve in his report, but skew was observed in the distribution of our data taking all age groups together.

A number of investigators have shown that hypertriglyceridemia can be induced in a normal subject by high carbohydrate diets. In spite of relative high intake of carbohydrate diet, the Japanese seldom develop hypertriglyceridemia. The discrepancy may be explained by the experiment carried out by Kuo et al., ${ }^{25)}$ who had shown that an increase in the portion of carbohydrates supplied sucrose was followed by a marked rise in serum triglyceride concentration and by a lesser increase in cholesterol concentration. As pointed out by Albrink, the Japanese diet contains an average of $350 \mathrm{gm}$ of carbohydrate daily, of which only 10 to $40 \mathrm{gm}$ is purified sucrose. In contrast, in America, of the average total carbohydrate intake of $300 \mathrm{gm}$ up to $100 \mathrm{gm}$ or more is composed of purified sucrose.

Since Albrink et a1. ${ }^{23)}$ suggested that elevated serum triglyceride levels might be related to the pathogenesis of ischemic heart disease, several investigators ${ }^{26)-27)}$ confirmed the results 
and conclusions of Albrink, and proposed that the serum triglyceride level is more closely associated with coronary heart disease than in serum total cholesterol.

In our investigation the triglyceride level in patients with coronary heart disease is likely higher than the control in normal persons, but a statistically significant difference could not be proven between them. These inconsistencies may be explained from the fact that coronary heart disease among the Japanese over 40 years of age is apt to take the form of intramuscular sclerosis of the coronary artery and the lesion is independent of the atherosclerosis in coronary stem.

As Olson et al. ${ }^{29)}$ have pointed out, the beta lipoprotein molecules serve as a transport system for triglycerides and contain significant amounts of cholesterol. Increases in these low density lipoproteins bring about increases in the cholesterol or triglyceride concentration in the blood. Since the separation of beta lipoprotein from $\alpha$-lipoprotein was succeeded by Burstein and Samaille ${ }^{30)}$ using dextran sulphate, the beta lipoprotein was approximately able to be determined simply and rapidly.

Burstein et al. ${ }^{30)}$ reported that beta lipoprotein lipid increases in both sexes ages from 25 to 55 years, and male values are consistently higher than female ones. Ledvina ${ }^{31)}$ determined the beta lipoprotein lipids by the modification of Burstein and Samaille in 800 normal blood donors and found that the levels increased with the advance of age till 55, but from 70 years it tend to decrease. Kellen ${ }^{32)}$ compared the beta-lipoprotein lipid level of 2065 normal blood-donors in fasting state and perceived that the average values increased from 20 to 45 years in both sexes but the male exhibited higher value than female.

As shown in Fig. 1, our data indicates that beta-lipoprotein lipids tend to increase with age but the age differences are statistically not significant. Yasuda ${ }^{33)}$ measured beta-lipoprotein lipid with dextran-sulphate in clinically normal Japanese and found the increment in concentrtion with age in both sexes.

Badin $^{34)}$ put emphasis on the Burstein method in so far as this method has the advantage of detecting ischemic heart disease among atheromatic patients over other methods. Ledvina put forward "beta-lipoprotein-index", which shows over 1 in the ischemic patients, that means ischemic heart disease patients take higher values in beta-lipoprotein lipid in proportion to the values of normal parson in the comparative age. Yasuda ${ }^{33)}$ obtained an increased concentration of beta-lipoprotein in patients with coronary heart disease. Our data also indicate that in male patients suffering from ischemic heart disease a significant higher level in betalipoprotein lipid is shown compared with a normal group, but in females over 40 years no significant difference can be found between coronary and healthy groups.

$\alpha$-lipoprotein cholesterol can be obtained subtracting $\beta$-lipoprotein cholesterol, which was estimated indirectly by turbidity tests, from total cholesterol. Searcy et al. ${ }^{35)}$ investigated clinically healthy subjects (male 554, femals 529) from 10 to 72 years of age, and found that $\alpha$-cholesterol did not appear markedly affected by age in either sex. $\beta$-lipoprotein cholesterol and serum total cholesterol revealed a substantial rise during the third and fourth decades in male. In females, however, higher values could be observed in the postmenopausal decades. In males of a comparable age this was not so. This suggests that the increase of total cholesterol with advance of age may be attributed to the rise of beta-lipoprotein cholesterol content. Leveille et al. ${ }^{36)}$ determined the lipid distribution in the $\alpha$-lipoprotein fraction of human plasma by polyanion precipitation method and observed about $30 \%$ of the total cholesterol was bound to the $\alpha$-lipoprotein fraction. Dangerfield et al. ${ }^{7)}$ estimated that about $35 \%$ of the total plasma level of cholesterol was present in the form of $\alpha$-lipoprotein cholesterol in the fasted normal subjects. Our data indicate that $\beta$-lipoprotein cholesterol account for about two thirds of total serum cholesterol in the healthy twenties and the ratio remained 
unchanged in fifties. The increase of total cholesterol in coronary heart disease patients 40-59 years may be due to the rise of $\beta$-cholesterol level.

Epidemiological and pathological studies have demonstrated that hypertension promotes the acceleration of atherosclerosis but the reverse, atherosclerosis is sited as a cause of hypertension, is untenable.

Hatch et al. ${ }^{37)}$ observed that the total lipids and cholesterol are in the normal range in essential hypertension. They noted no difference between hypertensives and healthy subjects of the same age. Harris ${ }^{38)}$ had concluded that the serum cholesterol level is proportionate to the systolic pressure. Malmros et al. ${ }^{39)}$ investigated the relationship between total serum cholesterol and systolic pressure in healthy men in Sweden and found no definite correlation between them. Waris ${ }^{40)}$ studied the lipid and lipoprotein levels in the sera of hypertensive patients in Norway. The serum total cholesterol levels in hypertensives did not differ essentially from healthy controls. A slight tendency of the beta-lipoprotein cholesterol level which increased with the severity of the disease was noted in the hypertensives. The mean level of beta-cholesterol in hypertensives was higher than in the control, but difference is statistically not significant. Parrish ${ }^{41)}$ studies autopsy reports of 2,731 white men aged 40 or over, and attempted to correlate hypertension with degree of coronary narrowing, and found the correlation was definite. He suspected that hypertension has adverse effects on ischemic heart disease by accerelating the sclerosis of coronary arteries and ascertained that the increase of coronary heart disease is greater in patients with hypertension. Dreyfuss et al. ${ }^{42)}$ investigated members of a population which had recently migrated to Israel from the Atlas Mountain Region of North Africa. These people had surprisingly little evidence of coronary vascular disease and at the same time their serum cholesterol levels were low. These people, however, were found to have a relatively high incidence of essential hypertension. Their diet may be poor in protein or fat, since they carried on their former living habits. The report suggests that some populations can maintain a low level of serum cholesterol despite the advance of age. The incidence of coronary disease is low in these populations even though heperten. sion may exist.

Our study indicates that hypertensive groups show a higher level in every area of serum lipid and lipoprotein compared with that of normal groups. Stage 2 group in hypertension especially shows statistically significant differences in the greatest number of items compared with the other groups. Hypertension at any stage of development, in the males over 60 years of age shows a statistically significant higher level of serum lipid and lipoprotein. It may be due to a rather low value of the adopted criterion in elderly hypertensive subject, viz. 160/90 was taken as the upper limit of normal level.

\section{SUMMARY}

The serum lipids and lipoproteins of 215 men and women over 20 years of age in Tokyo and its suburbs were investigated. The serum cholesterol and triglyceride levels in healthy subjects were below Western countries figures. In healthy men, age trends were observed only in the serum cholesterol content. In male and female hypertensives as well as subjects suffering from ischemic heart disease, every lipid component and lipoprotein showed a higher value as compared with that of normal persons. The serum triglyceride levels were elevated significantly in hypertensives but not significantly in subjects with ischemic heart disease compared with those of a normal control group. Total serum cholesterol, beta-lipoprotein lipids and cholesterol revealed significantly higher values in male hypertensives as well as the patients with ischemic heart disease from 40 to 59 years in comparison with a normal control 
in a comparable age group. There were no significant differences in the serum lipids and lipoprotein levels among the subjects at any stage of developing hypertension.

\section{ACKNOWLEDGMENT}

The authors wish to thank Miss Noriko Tokunaga for her invaluable technical assistance.

\section{REFERENCES}

1) Donomae, I., Matsumoto, Y. and Ueda, E.: Geriatrics, 20, 179-193, 1965.

2) Ueda, H.: Am. J. Cardiol, 10, 371-9, 1962.

3) Komachi, Y., Ozaka, H., Iida, M. Tominaga, S., Watanabe, M. and Sakamoto, S.: The Saishin-igaku, 19, (6), 1414-22, 1964.

4) Arterial hypertension and ischemic heart disease, WHO, Geneva, 1962.

5) Abell, L. L., Levy, B. B., Brodie, B. B. and Kendall, F. E: : J. Biol. Chem., 195, 357-366, 1952.

6) Kawade, M.: Mie Med. J., 11, (3), 399-407, 1962.

7) Dangerfield, W. G. and Faulkner G.: Clin. Chim. Acta, 10, 123-133, 1964.

8) Zak, B.: Amer. J. Clin. Path., 27, 583-587, 1957.

9) Ueda, H.: Japanese J. Clin. Med., 23, (9), 11-18, 1965.

10) Hayashi, Y., Genba, T., Yanaka, M. Chin, B. K., Ishii, T., Toyama, Y., Iwado, M. and Kimura, H.: Medicine and Biology, 69, (2), 85-89, 1964.

11) Lund, J. C., Sivertssen and Godal, H. C.: Acta Med. Scandinav, 169, (6), 623-7, 1961.

12) Carlson, L. A.: Acta Med. Scandinav., 167, (5), 377-397, 1960.

13) Schilling, F. J., Christakis, G. J., Bennett, N. J. and Coyle, J. F.: Amer. J. Public Health, 54, (3), 461-76, 1964.

14) Albrink, M. J.: Arch. Inter. Med., 109, 145-159, 1962.

15) Kroman, H., Nodine, J., Bender, S. and Brest, A.: Amer. J. Med. Scien., 248, 571-580, 1964.

16) Scarborough, W. R., Smith, E. W. and Baker, B. M.: Amer. Heart J., 59, 19-35, 1960.

17) Obeyesekere, J.: Brit. Heart, J., 26, 625-630, 1964.

18) Gore, I., Nakashima, T., Imai, T. and White, P. D.: Am. J. Cardiol., 10, 400, 1962.

19) Habel, R. J. and Carlson, L. A.:- Metabolism, 11, (2), 195-197, 1962.

20) Kunito, Y.: J. Osaka City Medical Center, 13, (7-9), 101-115, 1964.

21) Ahrens, E. H., Jr., Hirsch, J., Insull, W., Jr., Tsaltas, T. T., Blomstrand, R. and Peterson, M. L.: Lancet, 1, 943, 1957.

22) Brown, B. H. and Page, I. H.: JAMA, 173, 248-252, 1960.

23) Albrink, M. J. and Man, E. B.: Arch. Int. Med., 103, 4-8, 1959.

24) Lees, R. S. and Fredrickson, D. S.: Clin. Research, 13, 327, 1965.

25) Kuo, P. T. and Bessett, D. R.: Ann. Int. Med., 62, 1199-1212, 1965.

26) Albrink, M. J., Mergs, J. W. and Man, E. B.: Am. J. Med., 31, 4, 1961.

27) Carlson, L. A.: Acta Med. Scandinav., 167, 399-413, 1960.

28) Brown, D. F., Kinch, S. H. and Doyle, J. T.: New Engl. J. Med. 273, (18), 947-952, 1965.

29) Olson, R. E. and Vester, J. W.: Physiol. Rev., 40, 677, 1960.

30) Burstein, M. and Samaille, J.: Presse Méd., 66, (43), 974-5, 1958.

31) Ledvina, M., Mund Lubavstik, R.: Zschr. Inn. Med., 16, (1), 272-8, 1961.

32) Kellen, J.: Zschr. Inn. Med., 19, (1), 43-45, 1964.

33) Yasuda, Y.: Jap. Circul. J. 27, (7), 519-27, 1963.

34) Badin, J.: Presse Méd., 73, (47), 2659-63, 1965.

35) Searcy, R. L., C̣arroll II, V. P., Davis, W. H. and Bergquist, L. M.: Lancet II, 1196, 1960.

36) Leveille, G. A., Shockley, J. W. and Sanberlich, H. E.: Proc. Soc. Exp. Biol. Med., 108, 544-547. 1961.

37) Hatch, F. T. and Kendall, F. E.: J. Clin. Invest., 31, 636, 1952.

38) Harris, I.: Lancet II, 283, 1949.

39) Malmros, H., Blörek, G. and Swahn, B.: Acta Med. Scand. inav. Supple., 312, 71-78. 1956.

40) Waris, E.: Acta Med. Scand. inav. Suppl., 337, 1-79, 1958.

41) Parrish, H. M.: J. Chronic Diseases, 14, 326, 1961.

42) Dreyfuss, F., Hamosh, P., Adam, Y. G. and Kallner, B.: Am. Heart J., 62, (4), 470-7. 1961. 


\title{
高血圧症及び虚血性心疾患に於ける血清脂質
}

\author{
及びリポプロティンについて
}

\section{昭和大医衛生学教室}

小池 重夫 · 駒谷美智子 - 生 駒賢治 - 堀内英子

東芝林間病院

永見。忠孝

東京とその周辺の 20〜75歳の住民 215名について血清脂質及びりポプロティンを調查した。健常人の血清 トリクリセライド及びコレステロール值を欧米人の正常值に比でると各年令で何れる低かった。健常人では 乙れ等の諸值の内, 血清コレステロール值だけが加命汇伴って上昇した。高血圧症及び虚血性心疾患の既往 歴または現症をむつ群の血清脂質及びリポプロティンは何れる同年令の健常群代比べて高い值を示した。然 し統計的に有意の差を示したのは，血清トリグセライドでは健常群て比べて同年令の高血圧群のみで，虚血 性疾患群は有意の高值を示さなかっった。また総コレステロール, $\beta$-リポプロティン脂質, 及び $\beta$ ーリポプロ ティンコレステロールでは40〜59歳の男子の高血圧症群及び虚血性心疾患群だけが同年令の健常群に比へてて 統計的化有意に高い值を示した。高血圧の $1 ， 2 ， 3$ 期の間には血清脂質及びリポプロティン值で有意の差が 見られなかった。

（受付 1967 年 3 月23日） 